\title{
The Effect of Financial Compensation and Work Environment on Employee Satisfaction and Performance CV. Amri Jaya Dinamika of Pekanbaru City
}

\author{
Kasman ${ }^{a, *}$ Agus Seswandi ${ }^{b, *}$ \\ a Magister of Management, Postgraduate Program, Universitas Lancang Kuning, Indonesia.
}

\begin{abstract}
This study aims to determine and analyze the effect of Financial Compensation and Work Environment on job satisfaction and employee performance. To find out and analyze the effect on job satisfaction. The effect of financial compensation and work environment on performance through job satisfaction and the effect of satisfaction on employee performance. The data sources of this research are primary data and secondary data. With 105 employees as the research sample. The data analysis used in this study is PLS Structural Equation Modeling (SEM) which is operated through the SmartPLS program. The results showed that financial compensation and work environment had an effect on job satisfaction and employee performance. Financial compensation and work environment have a significant effect on employee performance through employee job satisfaction. Employee job satisfaction has a significant effect on employee performance.
\end{abstract} ARTICLE HISTORY

\section{Introduction}

CV. Amri Jaya Dinamika in Pekanbaru City is one of the companies engaged in the manufacturing industry. This company makes car body / box. This company processes semifinished goods into finished goods that are ready to use. For this reason, employee performance is very important. Performance is one of the important behaviors at work because employee performance greatly affects organizational performance. Performance is still a problem that is always faced by management, so management needs to know the factors that affect employee performance. Performance is the result of work in terms of quality and quantity achieved by an employee in carrying out his duties in accordance with the responsibilities given to him Mangkunegara (2014). While the performance benchmarks according to Kasmir (2016) are quantity, quality and timeliness.

According to Robins (2010), performance is influenced by several factors, namely: compensation and work environment. While the same opinion was expressed by Kasmir (2016) which states that the factors that affect performance include compensation and job satisfaction. Furthermore, according to Edison, Emron, Anwar Yohny (2017) one of the 
factors that affect employee performance is compensation, work environment and job satisfaction.

Job satisfaction is another factor that can affect employee performance. The above statement is reinforced by (Robins, 2015) in his book which states that employees with a high level of job satisfaction have a positive attitude towards their work, while someone with a low level of job satisfaction tends to have a negative attitude towards their work. To see the level of employee satisfaction, it can be seen from how employees complete the work given by the company, namely whether or not the work that has been set by the company has been achieved.

Compensation is any form of award given to employees as a reward for the contributions they make to the organization or company (Pangabean, 2012). Nawawi (2012), states that financial compensation is an award/reward to workers who have contributed to realizing their goals, through activities called work. Financial compensation is everything that employees receive in return for their work (Handoko, 2012).

Then in addition to satisfaction and financial compensation, what affects performance is the work environment. The work environment is something that is around employees at work, whether physical or non-physical, directly or indirectly, which can affect individuals at work. In this condition, of course, it can cause an imbalance between work situations which include facilities, applicable regulations, social relations, cooperation between employees and result in employee discomfort.

Based on the background of the problem above, there is a gap, namely the difference in the results from previous studies that have been carried out (research gap). It can be seen that research (Fauzi, 2017), (Andriany, 2019) and (Ardianti et al., 2018) show that compensation and work environment affect satisfaction and performance, while research by Riansari and (Riansari \& Sudiro, 2016) and (Pioh \& Tawas, 2016) shows the opposite, namely compensation and work environment have no effect on satisfaction and performance. In addition to the research gap, there is also a gap phenomenon from the background of the problem that has been described, where the work of employees does not reach the target, compensation decreases and most of the work facilities are not good.

\section{Theoretical support}

\section{Performance}

According to Amir (2015:83) employee performance is a behavior or activity displayed by someone in relation to work assignments in a company, department, or organization, carried out according to their potential, in order to produce something meaningful for the organization, the wider community, or for himself. Performance is about doing the job and the results achieved from that work. Performance is also what is expected and how to do it (Wibowo, 2014). Sedarmayanti (2010) states that performance is a system used to assess and find out whether an employee has carried out his work as a whole, or is a combination of work results (what one must achieve) and competence (how one achieves it). 


\section{Job satisfaction}

Mangkunegara (2014: 122) states that job satisfaction is a feeling that supports or does not support a person related to his work. Job satisfaction is an individual's level of satisfaction that they get commensurate rewards from various aspects of the work situation of the organization where they work (Tangklisan 2014:164). Furthermore, Handoko (2012: 90) job satisfaction is an assessment or reflection of workers' feelings towards their work.

\section{Financial Compensation}

According to (Flippo, 2015) financial compensation is the price for services received or provided by others for the benefit of a person or legal entity. Meanwhile (Dessler, 2015) states that financial compensation is any form of payment or reward given to employees and arises from the results of the work itself.

\section{Work environment}

According to (Kartono, 2009) Stating "the work environment can be interpreted as the forces that influence, either directly or indirectly, on the performance of the organization or company. (Sedarmayanti, 2013) states that the work environment is a place where there are a number of groups in which there are several supporting facilities to achieve company goals in accordance with the company's vision and mission ". A work environment that is well maintained, comfortable and safe will encourage the improvement of employees' work attitudes mention by (Rahmat, 2019).

\section{Research method}

\section{Data Analysis}

The measurement scale used in this study to determine the responses of the respondents is to use a Likert Scale. The Likert scale is a scale that shows respondents' responses to an increase in product purchases. After the data is collected, then the data is analyzed using data management techniques. The data analysis used by the author in this study aims to answer the questions listed in the identification of the problem. The data analysis technique used in this study is PLS Structural Equation Modeling (SEM) which is operated through the Smart PLS version 3.2.7 program. 


\section{Results}

\section{Analysis of SEM-PLS}

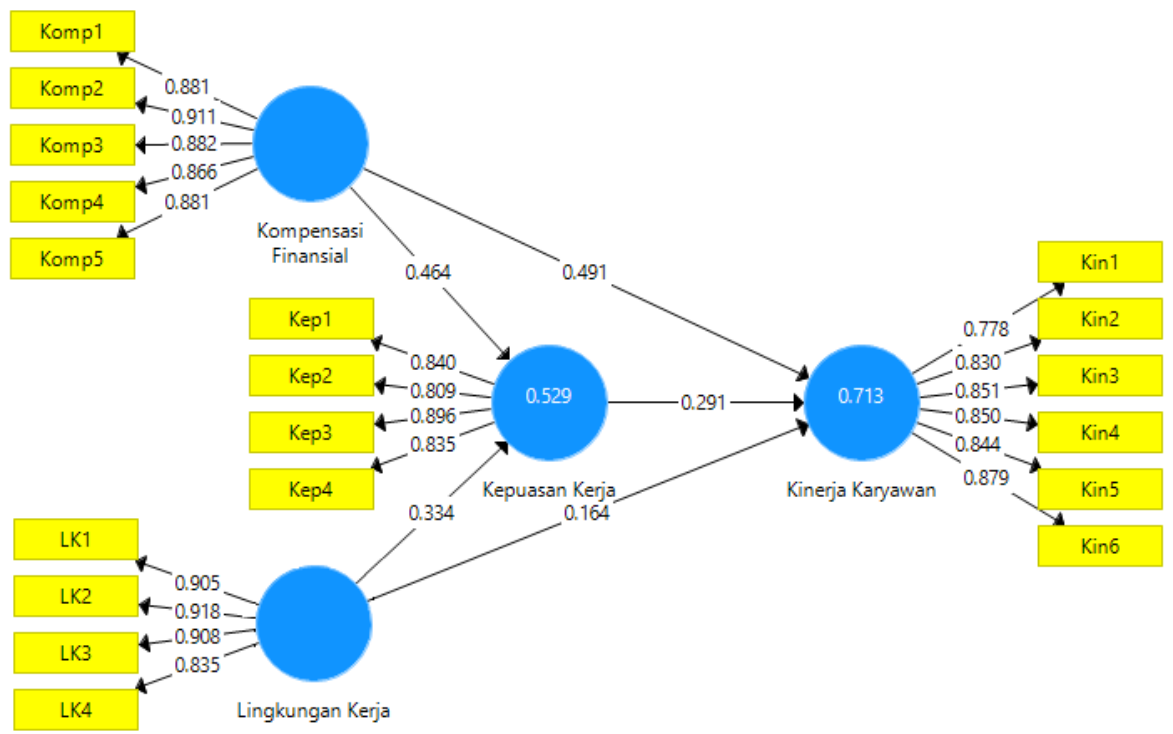

Figure 1. Path Chart.

\section{Direct Effect Hypothesis Testing Results}

Table 1. Direct Effect Hypothesis Test Results

\begin{tabular}{|c|c|c|c|c|c|}
\hline & $\begin{array}{c}\text { Original } \\
\text { Sample (0) }\end{array}$ & $\begin{array}{l}\text { Sample Mean } \\
\text { (M) }\end{array}$ & $\begin{array}{l}\text { Standard } \\
\text { Deviation } \\
\text { (STDEV) }\end{array}$ & $\begin{array}{c}\text { T Statistics } \\
\text { (|O/STDEV|) }\end{array}$ & P Values \\
\hline $\begin{array}{l}\text { Financial Compensation-> } \\
\text { Job satisfaction }\end{array}$ & 0.464 & 0.461 & 0.100 & 4.646 & 0.000 \\
\hline $\begin{array}{l}\text { Financial Compensation-> } \\
\text { Employee performance }\end{array}$ & 0.491 & 0.484 & 0.099 & 4.976 & 0.000 \\
\hline $\begin{array}{l}\text { Work environment-> } \\
\text { Job satisfaction }\end{array}$ & 0.334 & 0.338 & 0.102 & 3.288 & 0.001 \\
\hline $\begin{array}{l}\text { Work environment-> } \\
\text { Employee performance }\end{array}$ & 0.164 & 0.158 & 0.074 & 2.222 & 0.027 \\
\hline $\begin{array}{l}\text { Job satisfaction-> } \\
\text { Employee performance }\end{array}$ & 0.291 & 0.302 & 0.089 & 3.272 & 0.001 \\
\hline \multicolumn{6}{|c|}{$\begin{array}{l}\text { Notes. Processed Data Smartpls } 2021 \\
\text { The basis used in testing the hypothesis is the value contained in the following output path } \\
\text { coefficients: }\end{array}$} \\
\hline \multicolumn{6}{|c|}{$\begin{array}{l}\text { 1. The Effect of Financial Compensation on Job Satisfaction } \\
\text { Based on table } 1 \text { above, the effect of financial compensation on job satisfaction is } \\
\text { significant with a path coefficient value of } 0.464 \text { and a positive value, meaning that for } \\
\text { every increase in financial compensation of } 0.464 \text {, job satisfaction will increase by } \\
0.464 \text { units. Then obtained tstatistic } 4,646 \text { greater than } 1,983 \text { (ttable) and p value } 0.000 \\
<0.005 \text {, which indicates that there is an influence between Financial Compensation on } \\
\text { Job Satisfaction. Thus, in this study which states that "there is an influence between } \\
\text { Financial Compensation on Job Satisfaction". }\end{array}$} \\
\hline
\end{tabular}


2. The Effect of Work Environment on Job Satisfaction

Based on table 1 shows that the influence of the work environment on job satisfaction is significant with a coefficient value of 0.334 and a positive value, meaning that for every increase in the work environment of 0.334 , job satisfaction will increase by 0.334 units. Then obtained with tstatistic 3.288 greater than 1.983 (ttable) and p value 0.001 $<0.05$, which indicates that there is an influence between the work environment on job satisfaction. Thus in this study which states that "there is an influence of the work environment on job satisfaction.

3. The Effect of Financial Compensation on Employee Performance

Based on table 1 above, the effect of financial compensation on employee performance is significant with a path coefficient value of 0.491 and a positive value, meaning that for every increase in financial compensation of 0.491, employee performance will increase by 0.491 units. Then obtained tstatistic 4,976 greater than 1,983 (ttable) and $\mathrm{p}$ value $0.000<0.05$, which indicates that there is an influence between Financial Compensation with Employee Performance. Thus, in this study which states that "there is an influence between Financial Compensation on Employee Performance" is accepted.

4. The Influence of Work Environment on Employee Performance

Based on table 1 shows that the influence of the work environment on employee performance is significant with a path coefficient value of 0.164 and a positive value, meaning that for every increase in the environment by 0.164 , the performance will increase by 0.164 units. Then obtained with tstatistic 2.222 greater than 1.983 (ttable) and $\mathrm{p}$ value $0.027<0.05$, which indicates that there is an influence between the work environment on employee performance. Thus in this study which states that "there is an influence of the Work Environment on Employee Performance".

5. The Effect of Job Satisfaction on Employee Performance

Based on table 1 shows that the relationship between job satisfaction and employee performance is significant with a path coefficient value of 0.291 and a positive value, meaning that for every increase in job satisfaction of 0.291 , performance will increase by 0.291 units. Then obtained with tstatistic 3.272 greater than 1.983 (ttable) and $p$ value $0.001<0.05$ which indicates that there is an influence between Job Satisfaction on Employee Performance. Thus in this study there is an effect of job satisfaction on employee performance.

\section{Indirect Effect Hypothesis Testing Results}

Table 2. Indirect Effect Hypothesis Testing Results

\begin{tabular}{llll}
\hline & Original Sample (0) & $\begin{array}{l}\text { T Statistics } \\
(\mid \text { O/STDEV })\end{array}$ & P Values \\
\hline $\begin{array}{l}\text { Financial Compensation-> Job satisfaction-> } \\
\text { Employee performance }\end{array}$ & 0.135 & 2.409 & 0.016 \\
\hline
\end{tabular}




\begin{tabular}{llcl}
\hline $\begin{array}{l}\text { Work environment-> Job satisfaction-> } \\
\text { Employee performance }\end{array}$ & 0.097 & 2.057 & $\mathbf{0 . 0 4 0}$ \\
\hline Notes. Smartpls Processed Data 2021 & &
\end{tabular}

1. The Effect of Financial Compensation on Employee Performance Through Job Satisfaction

Based on table 2 shows that the effect of financial compensation on employee performance through job satisfaction is significant with a path coefficient coefficient of 0.135 and a positive value, meaning that every increase in job satisfaction of $0.135 \mathrm{can}$ indirectly increase the effect of financial compensation on performance by 0.135 units. Then obtained tstatistic of 2,409 which is greater than 1,983 (ttable) and p value of $0.016<0.05$, which indicates that there is an influence between Financial Compensation on Employee Performance through Job Satisfaction. Thus in this study which states that "there is an effect of Financial Compensation on Employee Performance through Job Satisfaction.

2. The Influence of Work Environment on Employee Performance Through Job Satisfaction

Based on table 2 above, the relationship between the work environment and employee performance through job satisfaction is significant with a path coefficient value of 0.097 and a positive value, meaning that every increase in job satisfaction of 0.097 can indirectly increase the effect of the work environment on performance by 0.097 units. Then obtained with tstatistic 2.057 greater than 1.983 (ttable) and p value $0.040<0.05$, which indicates that there is an influence between the work environment on employee performance through job satisfaction. Thus, in this study which states that there is an influence of the Work Environment on Employee Performance through Job Satisfaction.

\section{Discussions}

\section{Effect of Financial Compensation on Job Satisfaction}

On average, employees responded positively to the financial compensation provided by the company or on average stated they quite agree. This means that employees think that the financial compensation at the company is sufficient even though there are some employees who say it is insufficient. The results of this study are reinforced by the opinion of Ardianti et al., (2018) that compensation has an impact on employee job satisfaction, meaning that if good compensation is given, performance will also increase.

\section{Kerja The Effect of Work Environment on Job Satisfaction}

The findings in this study show that a person's job satisfaction can be determined from the surrounding work environment. This is because the work environment is a picture that shows a good relationship between superiors and subordinates, fellow co-workers, and adequate work facilities. The results of this study are reinforced by the findings of research conducted 
by Andriany (2019) stating that the work environment is one of the causes of a person's level of job satisfaction.

\section{The Effect of Financial Compensation on Employee Performance}

The employee's response to financial compensation, on average, stated that the compensation he received was adequate, although there were some employees who stated that the compensation they received was not good enough to cause dissatisfaction. Because some employees stated that their compensation was sufficient and there were still some employees who stated they were not satisfied, it resulted in the employees being less than optimal at work, so that their performance was less than optimal, this can be seen from the achievement of work results that have not been in line with the expectations of the company. This research is in accordance with that conducted by Pioh \& Tawas (2016) which states that the ups and downs of employee performance can be caused by compensation in accordance with their work. This shows that the size of the compensation given to the company will have an impact on the performance of an employee.

\section{Influence of Work Environment on Employee Performance}

Overall, the employees' response to the working environment is quite good, although it still needs to be improved. This means that the work environment is quite good, although there are some employees who say it is not too good because there are still some things that need to be improved. Furthermore, seen as a whole, the employee's response to the employee's performance partly stated that they quite agreed. This means that some employees already have quality, although there are some employees who need to get guidance, besides the quantity possessed by employees also needs to be considered so that they are able to carry out their duties with full responsibility and awareness in accordance with what has been determined by the company. The findings in this study are in accordance with the opinion of Yasa (2016) which states that a good work environment will have a good effect on employee performance, and vice versa if the environment is not good then employee performance will be difficult to improve.

\section{The Effect of Financial Compensation on Employee Performance through Job Satisfaction}

This study shows that financial compensation has an impact on employee performance through job satisfaction. This is because the provision of good financial compensation and in accordance with expectations will make employees feel satisfied, with satisfied employees the performance will increase, employees who receive appropriate compensation will feel happy, with feelings of pleasure employees will feel satisfied so that employee performance will experience enhancement. The findings of this study are supported by the opinion of Darma et al. (2018) job satisfaction mediates the effect of compensation on employee performance. This means that if the compensation given is able to make employees feel satisfied, it will have an impact on increasing employee performance. 


\section{The Effect of Work Environment on Employee Performance through Job Satisfaction}

The findings of this study indicate that the work environment will have an impact on employee performance through the level of employee satisfaction. This shows that the better the work environment and followed by positive employee job satisfaction will improve employee performance, because the more conducive the work environment, the higher the performance as seen from the high punctuality of work, quantity of work, and quality of work. The work environment does not have an indirect effect on employee performance through the intermediary of employee job satisfaction. The results of this study are reinforced by the findings of research conducted by Pioh and Tawas (2016) that job satisfaction is able to mediate the impact of the work environment on employee performance. This shows that the work environment is everything that is around the employee that can affect him in carrying out the work assigned to him.

\section{The Effect of Job Satisfaction on Employee Performance}

The findings of this study show that job satisfaction has a direct impact on employee performance, because employee performance will be able to be optimally optimized, if employee job satisfaction is considered, because good job satisfaction will certainly make someone work well and will have an impact on employee performance. The results of this study are reinforced by the findings of Dwijayanti's research (2015) which shows that satisfaction will have an impact on increasing employee performance, meaning that the higher a person's satisfaction, the greater the possibility of increasing their performance.

\section{Conclusion}

Financial Compensation has an effect on Employee Job Satisfaction CV. Amri Jaya Dinamika in Pekanbaru City. This shows that financial compensation can determine the level of employee job satisfaction. The better the Financial Compensation, the Job Satisfaction of CV employees. Amri Jaya Dinamika in Pekanbaru City will increase. Work Environment has an effect on Job Satisfaction of CV employees. Amri Jaya Dinamika in Pekanbaru City. This shows that the work environment is very important in determining job satisfaction. The better the work environment, the higher the job satisfaction of employees. Financial Compensation has an effect on Employee Performance CV. Amri Jaya Dinamika in Pekanbaru City. This shows that Financial Compensation can determine the level of Employee Performance. The better the Financial Compensation, the Employee Performance will increase. Work Environment has an effect on Employee Performance CV. Amri Jaya Dinamika in Pekanbaru City. This shows that the work environment can determine the level of employee performance. The better the Financial Compensation, the Employee Performance will increase. Financial Compensation has a significant effect on Employee Performance CV. Amri Jaya Dinamika in Pekanbaru City through Employee Job Satisfaction. So good financial compensation will make employees feel satisfied, with satisfied employees, performance will 
increase, this is because employees who get appropriate compensation will feel happy, with happy feelings employees will feel satisfied so that employee performance will increase. Work Environment has a significant effect on Employee Performance through Job Satisfaction CV. Amri Jaya Dinamika in Pekanbaru City. The better the work environment and followed by positive employee job satisfaction will increase employee performance. Job Satisfaction of employees CV. Amri Jaya Dinamika in Pekanbaru City has a significant effect on employee performance. The better the job satisfaction of employees will improve employee performance.

\section{Acknowledgement}

We thank the anonymous reviewers for their valuable support and guidance in improving the quality of the paper. Furthermore, we thank Adi Rahmat and Muhammad Rasyid Abdillah for his feedback on earlier versions of the paper. Besides, we also thank Universitas Lancang Kuning, Indonesia, for their assistance and support along the undertaken of this research.

\section{Disclosure statement}

No potential conflict of interest was reported by the authors.

\section{References}

Ahyari. (2014). Manajemen Sumber Daya Manusia dan Lingkungan Kerja. Pioner Jaya.

Amir, M. F. (2015). Memahami Evaluasi Kinerja Karyawan, Konsep, dan Penilaian Kinerja di Perusahaan. Mitra WacanaMedia.

Andriany, D. (2019). Pengaruh Kompensasi Dan Lingkungan Kerja Terhadap Kepuasan Kerja Karyawan Pada PT. Repex Perdana Internasional (License Of Federal Express) Medan. Proseding Seminar Nasional Kewirausahaan, 1(1), 392-398.

Ardianti, F. E., Qomariah, N., \& Wibowo, Y. G. (2018). Pengaruh Motivasi Kerja, Kompensasi Dan Lingkungan Kerja Terhadap Kepuasan Kerja Karyawan (Studi Kasus Pada PT. Sumber Alam Santoso Pratama Karangsari Banyuwangi). Jurnal Sains Manajemen Dan Bisnis Indonesia, 8(1), 13-31. https://doi.org/10.32528/smbi.v8i1.1764

Arikunto, S. (2014). Prosedur Penelitian Suatu Pendekatan Praktik. Rineka Cipta.

Darma, P. S., Supriyanto, A. S., Islam, U., Maulana, N., Ibrahim, M., \& Leadership, S. (2018). The Effect Of Compensation On Satisfaction And Employees. Management and Economics Journal, 1(1). https://doi.org/10.18860/mec-j.v1i1.4524

Davis, K. dan N. J. W. (2010). Perilaku Dalam Organisasi. Erlangga.

Dessler, G. (2015). Manajemen Sumber Daya Manusia. Salemba Empat.

Dwijayanti, M. N. (2015). Pengaruh Kompensasi Dan Lingkungan Kerja Terhadap Kepuasan Kerja Karyawan Pada Perusahaan Daerah Air Minum Tirta Mangutama Badung. Unud, E-Jurnal Manajemen, 4(12), 4274-4301.

Edison, Emron, Anwar Yohny, dan K. I. (2017). Manajemen Sumber Daya Manusia. Alfabeta.

Fauzi. (2017). Pengaruh Kompensasi Dan Lingkungan Kerja Terhadap Kepuasan Kerja Karyawan Pt. Tor Ganda Medan. 2(3), 36-47.

Ferdinand, A. (2013). Structural Equation Modelling dalam Penelitian. Manajemen. Universitas Dipenogoro.

Flippo, E. B. (2015). Manajemen Personalia. PT. Gelora Askara Pratma.

Gibson, Ivancevich, D. (2015). Organisasi, perilaku, Struktur dan proses, Edisi. Kelima. Erlangga.

Hair. (2014). A Primer On Partial Least Squares Structural Equation Modeling. (Pls Sem). SAGE.

Handoko, T. H. (2012). Manajemen Personalia dan Sumber Daya Manusia. BPFE Yogyakarta. 
Hasibuan, M. S. . (2013). Manajemen: Dasar, Pengertian, dan Masalah. Bumi Aksara. Indriantoro, N. and B. S. (2014). Metode Penelitian Bisnis, Edisi Pertama. BPFE Yogyakarta.

Januarty, W. (2020). Effect of Compensation and Work Environment on Employee Performance with Job Satisfaction as an Intervening Variable at PT. Putra Sejahtera Mandiri Vulkanisir. International Journal of Research and Review, 7(8).

Jogiyanto. Dan Abdillah. (2015). Partial Least Square (PLS) Alternatif SEM. Dalam Penelitian Bisnis. Andi Offset. Juliarti, P. A. D., Agung, A. A. P., \& Sudja, I. N. (2018). Effect of Compensation and Work Environment on Employee Performance with Employee Job Satisfaction as an Intervening Variable. International Journal of Contemporary Research and Review, 9(03), 20553-20562. https://doi.org/10.15520/ijcrr/2018/9/03/460

Kartono, K. (2009). Pimpinan dan Kepemimpinan. PT. RajaGrafindo Persada.

Kasmir. (2016). Manajemen Sumber Daya Manusia (Teori dan Praktik). PT. RajaGrafindo Persada.

Kusumah, D. H. (2016). Pengaruh Lingkungan Kerja Dan Kompensasi Terhadap Kepuasan Kerja Karyawan PT Sinar Lentera Kencana Cikarang. Jurnal Pengembangan Wiraswasta, 18(1), 71-80.

Lukiyana. (2016). Pengaruh Kompensasi Dan Lingkungan Kerja Terhadap Kinerja Karyawan Dengan Kepuasan Kerja Sebagai Variabel Intervening Pada PT. Pacific Metro International Jakarta. Media Studi Ekonomi, 19(2), 43-55. http://journal.uta45jakarta.ac.id/index.php/MSE/article/viewFile/561/343

Luthans, F. (2010). Perilaku Organisasi. PT. Andi Offset.

Machasin. (2018). Perilaku Organisasi. UR Press.

Mangkunegara, A. P. (2014). Manajemen Sumber Daya Manusia Perusahaan. PT. Remaja Rosdakarya Offset.

Mangkuprawira, S. dan A. V. H. (2013). Manajemen Mutu Sumber Daya Manusia. Ghalia Indonesia.

Mulyah;, S. A. H. (2020). Pengaruh Kompensasi dan Lingkungan Kerja Terhadap Kepuasan Kerja pada PT Kendari Ekspres. Jurnal Ilmu Manajemen, 6(01), 61-72.

Nawawi, H. (2012). Manajemen Sumber Daya Manusia. Gadjah Mada University Press.

Nitisemito. A. S. (2014). Manajemen Personalia. Graha Indonesia.

Novianto, D., \& Yuniati, T. (2015). Pengaruh Kompensasi dan Lingkungan Kerja Terhadap Kepuasan Kerja PT Galang Kreasi Sempurna. Jurnal ZIlmu Dan Riset Manajemen, 4(6), 1-16.

Pangabean, S. M. (2012). Manajemen Sumber Daya Manusia. Ghalia Indonesia.

Panggabean, S. M. (2014). Manajemen Sumber Daya Manusia. Ghalia Indonesia.

Pioh, N. L., \& Tawas, H. N. (2016). Pengaruh Kompensasi dan Lingkungan Kerja terhadap Kepuasan Kerja dan Kinerja Pegawai (Studi Pada PNS Di Kantor Kecamatan Sonder Kabupaten Minahasa ). Jurnal EMBA, $4(2), 838-848$.

Priansa, D. J. (2016). Perencanaan dan Pengembangan SDM. Alfabeta.

Sandra, W., \& Rahmat, A. (2019). Pengaruh Budaya Kerja dan Lingkungan Kerja Terhadap Kepuasan Pelanggan dengan Sikap Sebagai Intervening (Studi Kasus Di PT. Telkom Witel Ridar). Jurnal Manajemen dan Bisnis Terapan, 1(2), 97-107.

Riansari, T., \& Sudiro, A. (2016). Pengaruh Kompensasi dan Lingkungan Kerja terhadap Semangat Kerja dan Kinerja Karyawan ( Studi Kasus PT Bank TabunganPensiunan Nasional , TbkCabang Malang ). 66, 811820.

Riva’i, V. (2014). Manajemen Sumber Daya Manusia Untuk PerusahaanDari Teori ke Praktik. PT. RajaGrafindo Persada.

Robins, S. P. (2015). Perilaku Organisasi (10th ed.). Salemba Empat.

Samsudin, S. (2015). Manajemen Sumber Daya Manusia. Pustaka Setia.

Sedarmayanti. (2013). Sumber Daya Manusia dan Produktivitas Kerja. Mandar Maju.

Sekaran, U. (2015). Research Methods For Business (Metode Penelitian Untuk Bisnis). Salemba Empat.

Sihombing, S. (2014). Manajemen Sumber Daya Manusia. In Media.

Simamora, H. (2013). Manajemen Sumber Daya Manusia, Edisi 2. STIE, YKPN.

Soetjipto, B. W. (2012). Paradigm Baru Manajemen Sumber Daya Manusia. Amara Book.

Sugiyono. (2012). Metode Penelitian Kuantitatif, Kualitatif dan $R$ \& D.Bandung:Alfabeta. Metode Penelitian Kuantitatif, Kualitatif Dan R \& D.Bandung:Alfabeta. https://doi.org/10.1017/CBO9781107415324.004 
Kasman, The Effect of Financial Compensation ...

Tangklisan, H. N. S. (2014). Manajemen Publik. Grasiondo.

Tulenan, S. (2015). the Effect of Work Environment and Compensation Toward Employee Performance At the Office of State Assets and Auction Service Manado. Jurnal Riset Ekonomi, Manajemen, Bisnis Dan Akuntansi, 3(3), 672-682. https://doi.org/10.35794/emba.v3i3.9561

Wibowo. (2014). Manajemen Kinerja. Rajawali Press.

Wirawan. (2015). Manajemen Sumber Daya Manusia Indonesia. PT. RajaGrafindo Persada.

Yasa, I. P. S. (2016). Pengaruh Kompensasi Dan Lingkungan Kerja Terhadap Kepuasan Kerja Dan Kinerja Karyawan Pada Karma Jimbaran. Fakultas Ekonomi Dan Bisnis Universitas Udayana (Unud), Bali Indonesia, 1(1). 